\title{
Problem-solving and coping in family adaptation of children with Down Syndrome
}

\author{
Coping e resolução de problemas na adaptação familiar de crianças com Síndrome de Down \\ Afrontamiento y resolución de problemas en la adaptación \\ familiar de niños con Síndrome de Down
}

How to cite this article:

Braga PP, Silva JB, Guimarães BR, Van Riper M, Duarte ED. Problem-solving and coping in family adaptation of children with Down Syndrome. Rev Esc Enferm USP. 2021;55:e03708. doi: https://doi.org/10.1590/S1980-220X2020001803708

\section{Patrícia Pinto Braga ${ }^{1}$ \\ Juliana Barony da Silva² \\ Bárbara Radieddine Guimarães ${ }^{2}$ \\ Márcia Van Riper ${ }^{3}$ \\ Elysângela Dittz Duarte ${ }^{2}$}

${ }^{1}$ Universidade Federal de São João Del-Rei, Campus Centro-Oeste, Divinópolis, MG, Brazil.

2 Universidade Federal de Minas Gerais, Escola de Enfermagem, Belo Horizonte, MG, Brazil.

${ }^{3}$ University of North Carolina at Chapel Hill, Chapel Hill, North Carolina, United States.
Corresponding author:

Patrícia Pinto Braga

Av. Sebastião Gonçalves

Coelho, 400, Chanadour

CEP 35501-296 - Divinópolis, MG, Brazil

patriciabragaufsj@gmail.com

\section{ABSTRACT}

Objective: To analyze problem-solving and coping strategies of parents of children with Down Syndrome in family adaptation. Method: This is a qualitative research that used the Resiliency Model of Family Stress, Adjustment, and Adaptation. Participants were mothers and/or fathers from 40 families of children aged 1 to 7 years diagnosed with DS. Directed content analysis was performed, supported by software and considering a code dictionary. Results: Problem-solving and coping proved to be a set of actions, behaviors, efforts, and communications that contributed to family adaptation and favored balance between the demands imposed by Down Syndrome and the acquisition of resources by the family. Conclusion: In the first moment, which corresponds to the time of news or diagnosis of the syndrome and the first days after birth, internal and external resources, which represent coping, are developed to accept and refocus ideas and feelings towards Down Syndrome. Over time these resources have an effect and cause changes in family functioning patterns and in the relationship of these families with the outside world, as they seek child development.

\section{DESCRIPTORS}

Down Syndrome; Family; Adaptation, Psychological; Pediatric Nursing. 


\section{INTRODUCTION}

Down Syndrome (DS), the most common chromosomal disorder in humans, has an estimated worldwide incidence of 1 case per 1000 live births, and accounts for approximately $25 \%$ of cases of intellectual delay ${ }^{(1)}$. In Brazil, the estimate is 1 child for every 600 and 800 births, representing approximately 270 thousand people ${ }^{(1)}$. In this context, it should be considered that this population, especially children, has the specific therapeutic demands and the required care associated to the family's broader needs create a daily routine of accumulated demands and overloads ${ }^{(2)}$.

The experience of having a child with DS is unique and personal. Parents need to deal with the disease and the stress associated with the needs of this group of children ${ }^{(3)}$. Studies dedicated to analyzing resilience and adaptation in situations of chronic conditions have shown that even amidst adversities families can adopt behaviors and mobilize efforts that modify their functioning, making situations manageable and acceptable ${ }^{(3-4)}$. Such changes can contribute to the strengthening of parents and families as a whole. In the context of DS, professionals should be aware of circumstances that prevent or hinder family adaptation and should support and encourage families to adopt resources to cope with stressful situations ${ }^{(3)}$.

Specific efforts, at individual or family level, can be undertaken in the attempt to reduce demands and seek resources to deal with situations involving DS. From the perspective of the Resiliency Model of Family Stress, Adjustment, and Adaptation ${ }^{(5)}$, such efforts constitute coping behaviors. Coping should be seen as the coordination of behaviors for problem-solving of the family system as a whole, involving complementary individual efforts of its members, with the potential to bring balance between demands and resources and reduce difficulties ${ }^{(5)}$. Thus, coping refers to the way people interact with stressors and difficulties. In this regard, a set of mechanisms through which resources are identified to help individuals acquire lasting skills to manage crisis situations may emerge $e^{(6)}$.

Studies on family adaptation to chronic childhood conditions using the Resiliency Model of Family Stress, Adjustment, and Adaptation ${ }^{(5)}$ have been performed in different places worldwide, including children with $\operatorname{DS}^{(3,7)}$, autism ${ }^{(8)}$, genetic disorders and disability ${ }^{(9)}$, type 1 diabetes $^{(10)}$, congenital heart disease ${ }^{(11)}$, and extreme preterm infants ${ }^{(12)}$. Researches analyzing problem-solving and coping in situations involving $\mathrm{DS}^{(13-16)}$ have not addressed these components in the context of family adaptation, which points to the relevance of developing the present investigation. Considering the aforementioned, this study was developed based on the following question: in the process of family adaptation to the situation of having a child with DS, what are the problemsolving and coping strategies used by caregivers? Thus, this research aimed to analyze the problem-solving and coping strategies adopted by parents of children with DS in family adaptation.

This study is justified by the relevance of producing evidence about the set of actions, efforts and behaviors established by families that make situations involving DS more manageable. Identifying, knowing and predicting which resources families can use to adapt to the conditions inherent to DS will contribute to nursing management and decisionmaking concerning the care provided.

\section{METHOD}

\section{Study TYPE}

This is a qualitative research guided by the Resiliency Model of Family Stress, Adjustment, and Adaptation that allows analyzing the way a given stressor causes family crises and what are the strategies and resources adopted to make the situation more manageable and constructive for the family scheme $\mathrm{e}^{(5)}$. The model aims to explain the potential of parents and relatives to deal with crisis situations, and favors understanding factors related to family adjustment and adaptation ${ }^{(5)}$. Problem-solving and coping (PSC), in this research, are actions that favor change. Their function is to restore and contribute to balance between demands and resources and, at the same time, remove or reduce the difficulties that involve the stressful situation ${ }^{(5)}$.

\section{PARTICIPANTS}

Participants were 39 mothers and 3 fathers of children aged 1 to 7 years diagnosed with DS, living in two municipalities in the Midwest of Minas Gerais state, Brazil. These municipalities were intentionally chosen as settings due to data collection feasibility and because the study researchers were inserted in these contexts. The places for conducting all interviews were decided by participants, according to their availability, and included their places of work, residence, or institutions to which they are linked and where they receive care for DS. One father answered the interview individually and two responded together with the mothers. Therefore, one considered 42 participants from 40 families.

\section{SeleCtion CRITERIA}

Primary caregivers of children with DS aged 1 to 7 years were included in this study. The primary caregiver is the main person responsible for care and who meets most of the child's demands in their daily lives. To attract these participants, professionals who worked at institutions or associations that provide care for children with DS and their families initially recommended eligible caregivers, who were then contacted and invited. Seeking to increase the chances of including participants from families with different profiles and socioeconomic conditions, contact was made with organized groups of families of children with DS, and participants recommended other families that met the criteria.

\section{Data collection}

Data were collected between February and November 2017 using a semi-structured interview script based on the adopted theoretical framework. The interviews were conducted in a private place and were recorded with prior authorization of participants. Data collection was interrupted at 
the moment of theoretical data saturation; theoretical data saturation occurs when the information collected is sufficient to answer the question of the study ${ }^{(17)}$.

\section{DATA ANALYSIS AND PROCESSING}

The recorded interviews were transcribed by two of the researchers and then the transcriptions were checked for accuracy with the recordings. Each interview was numbered according to the order in which they occurred. To ensure anonymity and confidentiality, all names were replaced by letters $\mathrm{M}$ (Mother), $\mathrm{C}$ (Child), and F (Father), followed by the number corresponding to the order of the interview (e.g., C1, M1, F1). After transcription the material was analyzed using directed content analysis ${ }^{(18)}$, and the MAXQDA software, version 18 was used for data management and coding process.

The preliminary definition of codes was guided by the adopted theoretical framework. Then, 8 interviews were coded by two researchers, independently and simultaneously. Codings were compared and a Kappa index of 0.75 was obtained in inter-coder agreement. This was followed by coding of the other interviews by the same coders independently, and, in case of doubt, they would meet to reach an agreement. One considers that the entire investigative process adopted criteria that confer credibility, transferability, dependability and confirmation to the results, as advised by Guba and Lincon ${ }^{(19)}$.

\section{ETHICAL ASPECTS}

The research was approved by the Ethics Committee of Hospital Sofia Feldeman, according to the opinion 39746614.9.0000.5132. It is in compliance with Resolution 466/12 of the National Health Council on research with human beings. Before the interviews, participants gave their informed consent by signing the Informed Consent Form.

\section{RESULTS}

Participants' ages ranged from 19 to 49 years. Regarding marital status, 37 were married; two were divorced or separated; two were single; and one was widowed. Most children with DS (25) lived with their mothers, fathers and one or more siblings; 12 lived only with their mothers and fathers; two lived only with their mothers; and one lived only with the father. Ten children had no health insurance and used only the Unified Health System (SUS - Sistema Unico de Saúde).

The analytical data processing revealed four categories: Initial internal resources; Internal resources over time; Initial external resources; External resources over time. Internal resources are a set of initiatives, decisions, actions, communication and behaviors that involve family members, i.e., it would be the members' ability to deal internally and solve problems. External resources are a set of actions, communications and decisions that involve family members and their relationship with people or institutions that are not part of the family scheme, such as schools, health services or professionals, support groups. During analysis, it was necessary to distinguish the initial period and over time that involved DS. Initial period corresponding to the diagnosis period and the children's first days of life, situations over time already involved the children's continued growth and development.

PSC in crisis situations were presented considering the following elements ${ }^{(5)}$ : (a) appreciation at the family level (analyzes that contribute to assess meanings associated with a stressful situation); (b) stress management (actions and communication that contribute to managing stress resulting from a stressful event); (c) seeking assistance or support (actions aimed at acquiring support or additional responses that were not available to the family); (d) demand reduction (actions taken to reduce or eliminate the number or intensity of demands created by the disease).

\section{INTERNAL RESOURCES INITIAL}

Initial internal resources used by families who received the news and diagnosis of DS during pregnancy differ from those of families who received it after birth. Receiving the news during pregnancy, although recognized as difficult and painful, proved to offer the opportunity for most families to plan, prepare, and communicate with family members to deal with changes expected after the children's birth. The decision to prepare during pregnancy contributed to the process of accepting DS. Participants M25 and F25, despite having suspicion during pregnancy, chose not to confirm whether their child would be born with DS, but even so pointed out that it was possible to work on acceptance during pregnancy.

(...) so, when she was born, we had already defined these things. I told you that I was going to reduce [work] a little and take her to therapies. I think it was a good thing, because of this planning and acceptance (M4).

We knew it was going to be a girl and we knew she was going to have a heart problem, that it could be anything, and the physician was very upset with us because we didn't want to do the fetal karyotype because it was going to pose a risk to C25 and to the mother just to kill curiosity (F25).

Situations involving the diagnosis of DS during pregnancy and after childbirth were initially recognized as difficult, painful, and worrying. However, after birth, newborns' affective needs and care demands required caregivers to cope with the initial sadness and undertake actions that ensured care and decision-making to meet children's needs and demands. This appraisal process, even though difficult, contributed to reframe the situation experienced, recognizing that DS is not a disease.

At first, it was very difficult, we all in the family cried a lot, you know? My husband and I spent days crying like that, you know? (...) everyone suffered a lot, right? And as for me, it was kind of, I needed to restrain this sadness because I had to care for him, right?! (M22).

So, we got worried but at the same time relieved, because it's not a disease. It is simply one extra chromosome that he had that made him different from other people, but that was no problem, no (M16). 
The accep tance of DS, in the initial period, may be absent for a family member, however the support and communication with other family members are shown as a stress management resource that favored a more positive assessment of the situation.

The most difficult was for her (M7). She did not accept, in no way did she accept. Then, with a lot of conversation from me, with a lot of conversation from my sisters, from everyone in my family, from her mother. She has already become a little more real (P7).

\section{INTERNAL RESOURCES OVER TIME}

Over time, there is a reduction in the domestic budget caused, among other factors, by the expenses with professional care for the child and abandonment of work. Financial reorganization, reduced spending, and increased working hours are internal resources adopted by family members to address this problem.

We are a ware of the problem we are facing, this financial problem, (...) we cut several expenses right, the boys, who always studied in private schools, went to public school (M25).

We spend a lot of money, a lot! My whole salary is practically completely invested in his care, so I work another shift just to give my son living conditions (M22).

Communication and task sharing between different family members, routine organization, and priority setting are aspects that help to cope with situations and solve problems related to the different demands that arise. Challenges involving other children, i.e., the siblings of children with DS, emerge over time due to the amount of time that parents devote to care for children with DS, and also because of the need to have the help of siblings in this process. In these situations, the families resort to communication strategies and active participation of the siblings to manage tensions and help with care. Despite these challenges, participants recognize that there is family unity.

I stay with $C 7$ at night and his father stays with him in the morning. In the afternoon we both stay, or sometimes he leaves earlier to go to work (M7).

Talk to him and show him, [brother of the child with DS]: "C33 is already four years old, but she still behaves as a baby, so I need to take care of her; when you were four years old, you already took your shower alone, but with her, I need to give her a bath, so some things I need to do with her, for her, that you don't need me to do anymore". It is about trying to show these things to him (M33).

There is, there is support from my husband and my family, right, so, even my youngest son sometimes notices and says "Oh, Mom, are you sad? Do you want to talk?", then I say "Mom is so tired! "Oh, mom, don't be like that, you'll be well soon", just like we talk to him so that helps to be united (M26).

Due to the need of helping children to develop, the appraisal are internal resources used by families to help them acquire skills such as maintaining a stimulating routine, and recognizing, respecting and accepting that children with
DS, despite all the stimuli, may take more time to reach developmental milestones.

You have to learn how to see things differently so that you can use it on behalf of the child or in your routine, because taking the child to professional therapy is one thing, another thing is you turning her routine into constant stimulation (M31).

Over time, analyzes of families were identified regarding the future of children, especially related to the acquisition of independence and / or autonomy. These appraisal are permeated by uncertainties and insecurities, and different strategies are adopted or thought to deal with them, namely: investing in stimulation for skills acquisition, self-care and autonomy; recognizing children beyond the conditions of the syndrome; building hope that some family member will take care of that child when their parents are no longer present; identifying entitlements such as pensions and access to employment; recognizing the children's advancement and skill acquisition.

That is what I want to do. I want to raise him as an able child, an adult able to work, provide for himself, take care of his personal things. So, it's for that, to see these possibilities in him, and encourage from a young age his autonomy in life (M15).

I think that he [brother] is the one who will continue taking care of her when I'm gone, when I'm not here anymore to look after her. I think he's going to take over the care, because they both have a connection that has no explanation. And things go changing and our yearnings too. When she did not walk, I would say "if she gets to walk, this alone would be great". Then she began to walk, and that was no longer a concern. (...) do you realize how things change? Our yearnings, our needs also change! (M25).

In Chart 1, we present the initial internal resources and over time that represent coping and problem solving in the context of this investigation.

Chart 1 - Internal resources that represent problem-solving and coping strategies.

\begin{tabular}{|c|c|c|c|}
\hline Resources & Initial & Over time & Groups \\
\hline \multirow{3}{*}{ Internal } & $\begin{array}{l}\text { - Preparation } \\
\text { and planning } \\
\text { for changes } \\
\text { involving } \\
\text { children with } \\
\text { DS; } \\
\text { - Recognition } \\
\text { that DS is not a } \\
\text { disease. }\end{array}$ & $\begin{array}{l}\text { - Support and unity } \\
\text { development and } \\
\text { recognition among } \\
\text { members; } \\
\text { - Recognition and } \\
\text { acceptance of } \\
\text { singularities of } \\
\text { children with DS; } \\
\text { - Preparation and } \\
\text { planning for the } \\
\text { child's future. }\end{array}$ & Appreciation \\
\hline & $\begin{array}{l}\text { - Intrafamily } \\
\text { communication } \\
\text { use to seek } \\
\text { support to deal } \\
\text { with diagnosis. }\end{array}$ & $\begin{array}{l}\text { - Priority setting } \\
\text { and routine } \\
\text { reorganization; } \\
\text { - Financial } \\
\text { reorganization; } \\
\text { - Task and decision } \\
\text { sharing; } \\
\text { - Mediation of } \\
\text { situations involving } \\
\text { siblings; }\end{array}$ & $\begin{array}{l}\text { Stress } \\
\text { management }\end{array}$ \\
\hline & $\begin{array}{l}\text { - Care provision } \\
\text { required for } \\
\text { newborns with } \\
\text { DS. }\end{array}$ & & $\begin{array}{l}\text { Assistance or } \\
\text { support search }\end{array}$ \\
\hline
\end{tabular}




\section{EXTERNAL RESOURCES INITIAL}

We identified the search for assistance or support in the initial period, such as information search about DS, health care, rights and support groups to help deal with situations that involve the period right after diagnosis. Information search and belief in God were resources adopted in this first moment. I felt desperation at first, but then I started, I have to make it, I have to take him to a speech therapist, to physical therapy, let's do physical therapy (...) I've been chasing after everything. It's not easy, I'm spending a lot with bus tickets, let's go after free pass, so that's how it went, got it? (M19).

First, we looked for physicians to know the degree of difficulty we were going to have, but before the physicians, we looked for God (...) and we searched for some information on the internet (M32).

\section{EXTERNAL RESOURCES OVER TIME}

Over time, in relation to the search for information, there was a change in the nature of the information that became related to school development and inclusion content.

I study, but basically I see what is important to bim and I seek these services. I read about everything, about inclusion in school, even to try to enforce his right (M22).

Over time, choosing to improve the care of your child with DS induces stress management related to parents' employment, such as quitting a job, reducing workload, changing the workplace to be closer to home, and negotiating and/or making flexible schedules to go with their children to therapies. Other caregivers decided to continue with their jobs because the necessary care and expenses with their children left no alternative.

Ah, I quitted my job to take care of him. I think the biggest change that happened was this one. I had a job until he was born, so since his mother had very serious postpartum depression I stopped working so I could take care of him, take bim to do physical therapy, speech therapy, and so on (F2).

When I went back to work, things got complicated, so what I had to talk here, people already knew, I said "look, I'll have to leave every day at a certain time to take him, to walk him, and leave him at home and come back" (M1).
The use of medication was identified as a resource used by a mother to help manage everyday stresses.

Lots of antidepressants, I take too much antidepressants to handle it, and him [child with DS]! He is the one who refreshes me every minute, right? He is gorgeous, very fancy, him and the antidepressants (E36).

Child insertion in the school environment is marked by the search for different resources such as meetings with school professionals, mediation between school and health professionals (physiotherapists, speech therapists, etc.), and adaptations of school activities.

Because the issue of homework is not just that he is awake and having someone to help him with it, it is that homework has to be adapted entirely. They are very visual (...) you have to mediate, his duty is all mediated, so we have to learn to mediate and he is willing to do it, so we have to do it too (M31).

I talk a lot at school, right? I always schedule meetings to talk and the therapists, they go the o school too, right? They inform the school of some of his needs, give some guidelines (M22).

Participants said there is a demand reduction over time thanks to the use of the following strategies: choice of a strategic place to live, to facilitate the routine such as looking for a school near home, and reduce the travels by bringing health service therapies to be conducted at home, decisions about the routine that allows the best performance of children, and review of the amount of activities children perform.

So, the school is close to home, that's great, but that's on purpose, we went to live there, near the school. (...) we said we have to live here, so it's all close, to help us handle all we have to do (M40).

Her schedule is very busy, I've even been concerned and I doubt about if this good, because nobody discharges her, right? But I think we have to rethink things, I think she is super overloaded; she is, and I am too, consequently (M24).

The data analysis showed that external resources are a set of behaviors, actions and communications that represent family PSC in situations involving DS, as shown in Chart 2.

Chart 2 - External resources that represent problem-solving and coping strategies.

\begin{tabular}{|c|c|c|c|}
\hline Resources & Initial & Over time & Groups \\
\hline \multirow{3}{*}{ External } & $\begin{array}{l}\text { - Information search about the } \\
\text { syndrome; } \\
\text { - Health care, rights and support } \\
\text { group search; } \\
\text { - Belief in God; }\end{array}$ & $\begin{array}{l}\text { - Information and strategy search for stimulation; } \\
\text { - Maintenance of health care, exercise of rights, and } \\
\text { support groups; } \\
\text { - Belief in God; }\end{array}$ & Assistance or support search \\
\hline & & $\begin{array}{l}\text { - Medication use; } \\
\text { - Decisions or negotiation about employment; } \\
\text { - Adoption of strategies to favor school insertion and } \\
\text { inclusion; }\end{array}$ & Stress management \\
\hline & & $\begin{array}{l}\text { - Travel reduction for child care; } \\
\text { - Review of the amount of consultations for child care. }\end{array}$ & Demand reduction \\
\hline
\end{tabular}


In summary, one presents in Figure 1 internal and external resources that represented PSC strategies, that contributed to the process of adjustment and adaptation of families of children with DS. One emphasizes that internal resources influence and interfere with external resources and vice versa, composing a dynamic set of interactions between these measures, families and the context, in the adaptive process.

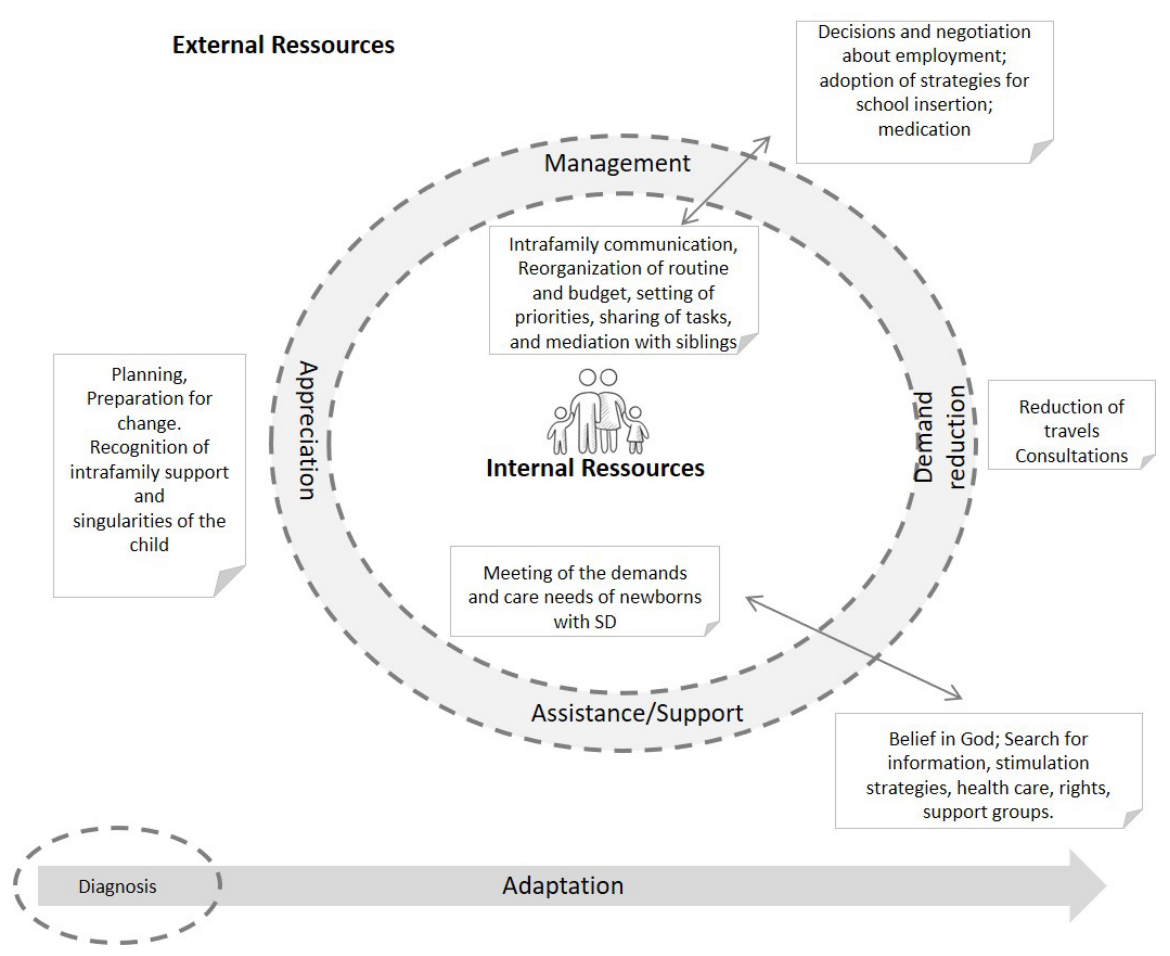

Figure 1 - Internal and external resources representing problem-solving and coping.

\section{DISCUSSION}

Family appreciation in the initial moments and over time contributes to developing internal family resources as family members assess and analyze the meanings associated with DS and try to make this experience more constructive, manageable, and acceptable to the family scheme. In light of the framework adopted in this study ${ }^{(5)}$, one can infer that analysis of situations involving DS allowed preparing, planning for changes and for the future, developing the capacity of intrafamily support and unity, and recognizing and accepting the singularities of a child with DS, re-defining the situations experienced.

A study with families of children with DS showed that families and their members are capable of abstracting positive meanings from the adversities faced, and establishing a new meaning for the condition ${ }^{(4)}$. Allied to this, it is identified that family communication skills, cohesion among its members, and support and quality of health services contribute to family adaptation ${ }^{(3,20)}$. Researchers have suggested that nursing interventions should consider these aspects to promote resilience $^{(20)}$.

Internally and initially, the family seeks to organize itself to assist the new born in their care needs and demands, and this can be recognized as a coping and problem solving strategy. As external resources that represent the search for assistance or support, we find a search for information, initially about DS and over time about stimulation and inclusion, search for health care, rights and support groups, adoption of strategies for stimulation of the child, as well as belief in God.

Research that aimed to analyze the hope in mothers of children with DS and its association with coping behaviors adopted by the family and the quality of the relationship of these mothers with the parents indicated that belief in God or religiosity were significantly associated with greater hope and quality in the relationship among parents of children with $\mathrm{DS}^{(14)}$. Similar results are presented in research that shows that, faced with difficulties, families of children with DS resort to religious faith and become more involved with the care of their child ${ }^{(4)}$, seeking assistance from professionals and meeting with the pedagogical team of school to outline strategies that can solve or minimally allow to deal actively with the problem, increasing the sense of competence and indicating an active coping with the stressor ${ }^{(21)}$.

The internal resources that represent stress management are identified as the ability to develop intrafamily communication to deal with the diagnosis, adopt a reorganization of the family's routine and financial resources, incorporating strategies for setting priorities and sharing tasks and decisions. It is also identified the ability to mediate conflicting or overload situations that involve the siblings of the child 
with DS, and, in overcoming these conflicts, greater family unity is perceived.

Families of children with DS may have a capacity to organize their functioning in a cooperative manner, with dialogue, closer bonds, contributing to a positive and adaptive perspective $^{(4)}$. Together, professionals can promote adaptation by helping parents reduce stressors, find additional support, and value child and family development in dealing with situations ${ }^{(9)}$.

Studies devoted to understanding DS repercussions on siblings of children with DS have shown that they go through processes of acceptance, confusion, and various other complexities with which the syndrome is linked; yet, affective relationships and interaction competence between them are identified $^{(21,22)}$. Support groups for siblings may help families to cope positively with challenges in situations involving the adaptation of siblings of children with $\mathrm{DS}^{(23)}$.

As external resources adopted to manage tensions, one identified decisions and negotiations regarding employment and strategies that favor school insertion and inclusion of children. Comparative research between groups of children with normal developing and children with disabilities found that caregivers of the latter group are 3-fold more likely to experience concerns and stress regarding family budget ${ }^{(24)}$. Considering this fact and the findings of the present research, one can infer that families need to be supported in decisions involving work, because such decisions may affect or reduce the household budget. Family decisions about employment and financial reorganization proved to be a PSC strategy because they contributed to balance the demands presented by the child, the financial resources and the time the family had available to dedicate to children with DS.

The challenges with school inclusion of children with DS are evident in the data analyzed here, and this is confirmed by a Brazilian study ${ }^{(25)}$. However, in order to reduce the tension between the expectation to insert children in the school environment and the unpreparedness of educational institutions, families adopt strategies for communicating with the school and adapting teaching materials to enable the permanence and development of children with DS.

One understands, as Resiliency Model of Family Stress, Adjustment, and Adaptation ${ }^{(5)}$ argues, that demand reduction includes actions to reduce or eliminate the number or intensity of demands created by the condition. From this standpoint, in the present investigation, demand reduction included changing residence and therapy places so as to reduce commuting with children, making a reassessment in order to reduce the amount of consultations that children needed to attend.

Data analysis allows one to infer that the resources adopted by families to reduce demands are few, considering that these families experience overloads ${ }^{(2)}$. This finding is relevant as professional and nursing practices need to consider this aspect in order to encourage families to adopt demand reduction strategies in situations involving DS.

Based on the above, one infers that by developing initial internal resources the family will accept their children's condition and re-define DS. Over time, such internal resources made it possible to balance children's demands with the family's ability to meet them. Initial external resources enabled understanding DS and allowed to meet children's care needs. External resources were adopted over time to contribute to child development.

The analysis allowed one to infer that the resources that represent family PSC contributed to changes in family dynamics. In theory, the Resiliency Model of Family Stress ${ }^{(5)}$, Adjustment, and Adaptation argues that amidst a crisis situation, induced by a chronic condition, for example, families adapt by implementing changes in family patterns of functioning, in the scheme or structure, and changes in the family's relationship with the outside world. This premise is congruent with the results of this investigation as it was possible to identify the internal resources developed that impact on family dynamics and functioning and external resource acquisition, which also contributed to making situations more constructive, manageable, and acceptable.

As limitations of this study, most participants were linked to a specific setting, and this may not reflect the situation experienced in other cultural contexts, with access to different health care network services. Fathers were also underrepresented in the sample, and one is aware of the fact that interviews with other family members could bring complementary perspectives.

\section{CONCLUSION}

Initially, PSC strategies contributed for families to accept and reframe ideas and feelings related to DS. In this perspective, one recognizes that nursing and professional interventions in the period after diagnosis need help families to adopt resources such as: seeking information and knowledge about the syndrome and its future repercussions; developing effective intra-family communication; seeking support to care for newborns with DS; adopting planning and preparation strategies for changes in the family; establishing contact with groups of families of children with DS.

Over time, the resources adopted caused changes in family functioning patterns and in the family's relationship with the outside world. In this period, some articulated professional practices that promote family adaptation are: support to families to making assertive decisions regarding child growth and development; support for managing the tensions that arise over time, encouraging family members to talk with each other and share internally decisions about family routine; recognition and encouragement of the potential and beliefs of families, helping them to see and value the uniqueness of children with DS; guidance about rights to social inclusion.

It is appropriate to clarify that the existence of PSC strategies does not ensure a good adaptation, but identifying them allows an appreciation of which resources can be used to make the process manageable for the family scheme. Professionals can use the findings described here as clues to encourage families to better deal with situations involving DS. 


\section{RESUMO}

Objetivo: Analisar as estratégias de coping e resolução de problemas, de pais de crianças com Síndrome de Down, na adaptação familiar. Método: Investigação qualitativa, que utilizou o Modelo de Resiliência, Stress, Ajustamento e Adaptação Familiar. Participaram mães e/ou pais de 40 famílias, de crianças com idade entre 1 e 7 anos e diagnosticadas com Síndrome de Down. Realizou-se análise de conteúdo direcionada, apoiada por software, considerando um dicionário de códigos. Resultados: Coping e resolução de problemas se revelou como um conjunto de ações, comportamentos, esforços e comunicações que contribuíram para a adaptação familiar, favorecendo o equilíbrio entre as demandas impostas pela Síndrome de Down e a aquisição de recursos pela família. Conclusão: No período inicial, que compreende o momento da notícia ou diagnóstico da síndrome e os dias inicias após o nascimento, os recursos internos e externos que representam coping são desenvolvidos para aceitar e ressignificar ideias e sentimentos relacionados à Síndrome de Down. Ao longo do tempo, esses recursos repercutem em mudanças nos padrões familiares de funcionamento e na relação dessas famílias com o mundo externo, ao buscarem o desenvolvimento da criança.

\section{DESCRITORES}

Síndrome de Down; Família; Adaptação Psicológica; Enfermagem Pediátrica.

\section{RESUMEN}

Objetivo: Analizar las estrategias de afrontamiento y resolución de problemas de los padres de niños con Síndrome de Down en la adaptación familiar. Método: Investigación cualitativa, que utilizó el Modelo de Resiliencia, Estrés, Ajuste y Adaptación Familiar. Madres y/o padres de 40 familias participantes, niños de 1 a 7 años y diagnosticados de Síndrome de Down. Se realizó análisis de contenido dirigido, apoyado por software, considerando un diccionario de códigos. Resultados: El afrontamiento y la resolución de problemas se reveló como un conjunto de acciones, comportamientos, esfuerzos y comunicaciones que contribuyeron a la adaptación familiar, favoreciendo el equilibrio entre las demandas impuestas por el síndrome de Down y la adquisición de recursos por parte de la familia. Conclusión: En el período inicial, que comprende el momento de la noticia o diagnóstico del síndrome y los días que comienzan después del nacimiento, se desarrollan los recursos internos y externos que representan el afrontamiento para aceptar y replantear ideas y sentimientos relacionados con el Síndrome de Down. Con el tiempo, estos recursos repercuten en cambios en los patrones de funcionamiento familiar y en la relación de estas familias con el mundo exterior, en la búsqueda del desarrollo infantil.

\section{DESCRIPTORES}

Síndrome de Down; Família; Adaptación Psicológica; Enfermería Pediátrica.

\section{REFERENCES}

1. World Health Organization. Genes and chromosomal diseases [Internet]. Geneva: WHO; 2016 [cited 2020 Jan 12]. Available from: http:// www.who.int/genomics/public/geneticdiseases/en/index1.html

2. Barros ALO, Barros AO, Barros GLM, Santos MTB. Sobrecarga dos cuidadores de crianças e adolescentes com Síndrome de Down. Ciênc Saúde Coletiva. 2017; 22(11): 3625-34. doi: 10.1590/1413-812320172211.31102016

3. Caples M, Martin AM, Dalton C, Marsh L, Savage E, Knafl G, et al. Adaptation and resilience in families of individuals with Down Syndrome living in Ireland. Br J Learn Disabil. 2018;46:146-54. doi:10.1111/Bld.12231

4. Rooke M I, Pereira-Silva N L. Indicativos de resiliência familiar em famílias de crianças com Síndrome de Down. Estud Psicol (Campinas). 2016;33(1):117-26. doi: 10.1590/1982-027520160001000012

5. Mccubbin M, Mccubbin, H. Families coping with ilness: the resiliency model family stresse, adjustment, and adaptation. In: Danielson C, Hamel-Bissell B, Winstead-Fry P. Families, health \& ilness: perspectives on coping and intervention. St Louis: Mosby-Year Book; 1993. p. 21-63.

6. Zimmer-Gembeck MJ, Skinner EA. The Development of coping: implications for psychopathology and resilience. In: Cicchetti D, editor. Developmental psychopathology. Hoboken: John Wiley \& Sons; 2016. p. 1-61.

7. Van Riper M, Knafl G, Rosigno C, Knafl, K. Family management of childhood chronic conditions: does it make a difference if the child has an intellectual disability. A J Med Genet A. 2018;176(1):82-91. doi: 10.1002/ajmg.a.38508

8. Kapp L, Brown O. Resilience in families adapting to autism spectrum disorder. J Psychol Afr. 2011;21(3):45963. doi: 10.1080/14330237.2011.10820482

9. Hall HR, Neely-Barnes SL, Graff JC, Krcek TE, Roberts RJ, Hankins JS. Parental stress in families of children with a genetic disorder/ disability and the resiliency model of family stress, adjustment, and adaptation. Issues Compr Pediatr Nurs. 2012; 35(1):24-44. doi: $10.3109 / 01460862.2012 .646479$

10. Brown O, Fouché P, Coetzee M. Bouncing forward: families living with a type I diabetic child. S Afri Fam Pract. 2010;52(6):536-41. doi: h10.1080/20786204.2010.10874044.

11. Tak YR, McCubbin M. Family stress, perceived social support and coping following the diagnosis of a child's congenital heart disease. J Adv Nurs. 2002;39(2):190-8. doi:10.1046/j.1365-2648.2002.02259.x.

12. Shani-Sherman T, Dolgin MJ, Leibovitch L, Mazkereth R. Internal and external resources and the adjustment of parents of premature infants. J Clin Psychol Med. 2019;26(3):339-52. doi: 10.1007 / s10880-018-9583-6

13. Pisula E, Banasiak A. Empowerment in Polish fathers of children with autism and Down syndrome: the role of social support and coping with stress - a preliminary report. J Intellect Disabil Res. 2020;64(6):434-41. doi: 10.1111/jir.12681

14. Cless JD, Nelson GBS, Durtschi JA. Hope, coping, and relationship quality in mothers of children with Down syndrome. J Marital Fam Ther. 2018;44(2):307-22. doi: 10.1111/jmft.12249

15. Pourmohamadreza-Tajrishi M, Azadfallah P, Garakani SH, Bakhshi E. The effect of problem-focused coping strategy training on psychological symptoms of mothers of children with Down syndrome. Iran J Public Health. 2015;44(2):254-62.

16. Van Der Veek SMC, Kraaij V, Garnefski N. Down or up? Explaining positive and negative emotions in parents of children with Down's syndrome: Goals, cognitive coping, and resources. Am J Intellect Dev Disabil. 2009;34(3):216-29. doi: 10.1080/13668250903093133 
17. Nelson J. Using conceptual depth criteria: addressing the challenge of reaching saturation in qualitative research. Qual Res. 2016;17(5):55470. doi: $10.1177 / 1468794116679873$

18. Hsieh H-F, Shannon SE. Three approaches to qualitative content analysis. Qual Health Res. 2005;15(9):1277-88. doi: $10.1177 / 04973230527668$

19. Guba GE, Lincoln YS. Avaliação de quarta geração. Campinas: Ed Unicamp; 2011.

20. Choi EK, Yoo IY. Resilience In families of children with Down syndrome in Korea: family resilience and Down syndrome. Int J Nurs Pract. 2015;21(5):532-41. doi: 10.1111/ijn.12321

21. Reis LB, Paula KMP. Coping materno da Síndrome de Down: identificando estressores e estratégias de enfrentamento. Estud Psicol (Campinas). 2018;35(1):77-88. doi: 10.1590/1982-02752018000100008

22. Choi H, Van Riper M. Maternal perceptions of sibling adaptation in korean families of children with Down Syndrome: adaptation in siblings of children with Down Syndrome. J Intellect Disabil Res. 2014;58(10):962-77. doi: 10.1111/jir.12126

23. Batista BR, Duarte M, Cia F. A interação entre as pessoas com síndrome de Down e seus irmãos: um estudo exploratório. Ciênc Saúde Coletiva. 2016;21(10):3091-9. doi: 10.1590/1413-812320152110.17282016

24. Goudie A, Narcisse MR, Hall DE, Kuo DZ. Financial and psychological stressors associated with caring for children with disability. Fam Syst Health. 2014;32(3):280-90. doi: 10.1037/fsh0000027

25. Azevedo APD, Damke ASA. Criança com síndrome de Down: o sentido da inclusão no contexto da exclusão. Rev Educ Espec. 2017;30(57):103. doi: 10.5902/1984686X17862 